\title{
Basal Cell Carcinoma: A Patient and Physician's Experience
}

Barbara J. Cohen · Eliahou S. Cohen · Philip R. Cohen

Received: May 14, 2018 / Published online: June 2, 2018

(C) The Author(s) 2018

\section{ABSTRACT}

In this article, the first coauthor, a patient with a basal cell carcinoma on her upper lip, discusses her experience with Mohs micrographic surgery for the treatment of the skin cancer. The second coauthor, who is the patient's physician (a dermatologist who shares her last name but is not a relative), diagnosed her skin cancer and referred her for Mohs surgery. The third coauthor, who is the patient's son and not only a dermatologist, but also a dermatopathologist and a Mohs surgeon (and also shares her last name), summarizes the presentation and treatment of the basal cell carcinoma.

Keywords: Basal; Cancer; Carcinoma; Cell; Controlled; Experience; Micrographic; Mohs; Patient; Physician; Skin; Surgery; Treatment

Enhanced digital features To view enhanced digital features for this article go to https://doi.org/10.6084/ m9.figshare.6292811.

B. J. Cohen

Delray Beach, Florida, USA

E. S. Cohen

Advanced Dermatology and Cosmetic Surgery, Delray Beach, Florida, USA

P. R. Cohen $(\bowtie)$

Department of Dermatology, University of California San Diego, La Jolla, San Diego, CA, USA

e-mail: mitehead@gmail.com

\section{PATIENT'S EXPERIENCE}

When I was a young girl my parents thought it was healthy to put baby oil on one's skin before going outside to be in the sun. Little did they know that this action would cause so many problems for me once I grew up and became an adult.

Being fair-skinned and a redhead with blue eyes, I had many sunburns followed by big water blisters due to exposure to the sun's rays. As I became older, the dermatologist froze many areas of my body to correct the damage caused by the sun's rays in my youth.

I had my first Mohs surgery more than 50 years ago. This was on my face, and I remember having the doctor cut the affected area, cover it with a bandage, and send me back to the waiting room until the skin sample could be checked to make certain that all of the cancerous cells had been removed. Another time, again on another part of my face while I was still living in upstate New York, another Mohs surgeon did the same procedure. Fortunately, both of these men were excellent; I did not suffer from any discomfort and the scars were not noticeable.

Now, I am an 82-year-'young' patient. My son-Philip R. Cohen, MD-is a dermatologist; however, he practices in California. Recently, my current dermatologist-in Florida (where I live)—referred me to my third Mohs surgeon. 
It was the strangest thing as I thought I had scratched my face just above the right side of my upper lip. The scratch did not go away. I made an appointment to see my dermatologist and showed it to Dr. Eli Cohen; although we share the same family name, we are not relatives. He took a biopsy of the lesion and sent it to a dermatopathologist (Fig. 1). I was shocked when I received the call from his office; it was not a scratch, but a basal cell carcinoma.

Dr. Cohen said he was going to send me to the Mohs surgeon who had previously done several procedures on my husband.

I went to the Mohs surgeon thinking this would be a simple procedure just like my other two experiences. Wrong. The Mohs surgeon explained that the cancer area began above my lip and extended into my lip; therefore, this time the procedure would be bit more difficult and a bit more uncomfortable. He knew I was on a blood thinner and told me I had to stop it a few days before the operation so that I would not bleed profusely. I then became aware that I would have many stitches on my face, but the lip itself had to be handled differently. The doctor explained that I would need a pressure bandage since there would be small area that he would not stitch.

Naturally I was concerned and nervous. I was assured that everything would be all right, but that I would experience discomfort for a period of time.

The day of the surgery arrived. The area of my lip containing the skin cancer was anesthetized; I felt no discomfort from the procedure (Fig. 1). It was explained to me that I would feel pain later and that I could take acetaminophen for the pain. A huge area was bandaged and I felt quite awkward when I left the office (Fig. 2). I was told to make two appointments to see the Mohs surgeon: the first visit in 1 week for some of the stitches to be removed and the second visit the following week for the remaining stitches to be removed.

Later that day, I realized that being on a blood thinner made my surgery more difficult. Unfortunately, after I went home, I noticed that I had bled through the bandage. I called the Mohs surgeon's office; his staff told me to come back to the office the next day and they would change my bandage. When I arrived at the Mohs surgeon's office the next day his assistant carefully and gently removed the bandage. She said that the healing after the procedure was progressing nicely and that I should continue to do much better. She was correct; although I still was having significant discomfort and tightness in the area, I was no longer bleeding. Indeed, my biggest problem was that I am a person who smiles a great deal and it was painful to smile during this time.

When I returned to the office after the first week some of the stitches were removed. This was done in such a caring manner that I felt no discomfort from the procedure.

The following week the remainder of the stitches were removed; sure enough, I was able to smile without any pain. I could hardly tell I had an operation. I was healing so well and my face looked natural (Figs. 3, 4).

My only problem now is that I am a bit numb at the surgical site on the right side of my upper lip. However, I was informed that it could take up to 1 year for the normal sensation in that area to spontaneously return. I was also told to massage the area twice a day for $5 \mathrm{~min}$ at a time until my next appointment that will be in 1 month.

I have seen other people who had similar operations for skin cancer. Some of them did not have the wonderful outcome that I experienced. I feel very fortunate that I have had such excellent doctors.

In addition to my basal cell carcinoma, I also had several actinic keratoses that Dr. Cohen 'froze' with liquid nitrogen. Therefore, I have my skin examined by the dermatologist every 3-6 months. In addition, I will continue to apply sunscreen to my face, neck, and arms each day.

\section{PHYSICIAN'S PERSPECTIVE}

Basal cell carcinoma is the most common type of skin cancer [1]. Similar to Mrs. Cohen's tumor, it most frequently presents as a fleshcolored papule or nodule on a sun-exposed site, such as the face. Excision, using microscopically controlled margins (Mohs micrographic 

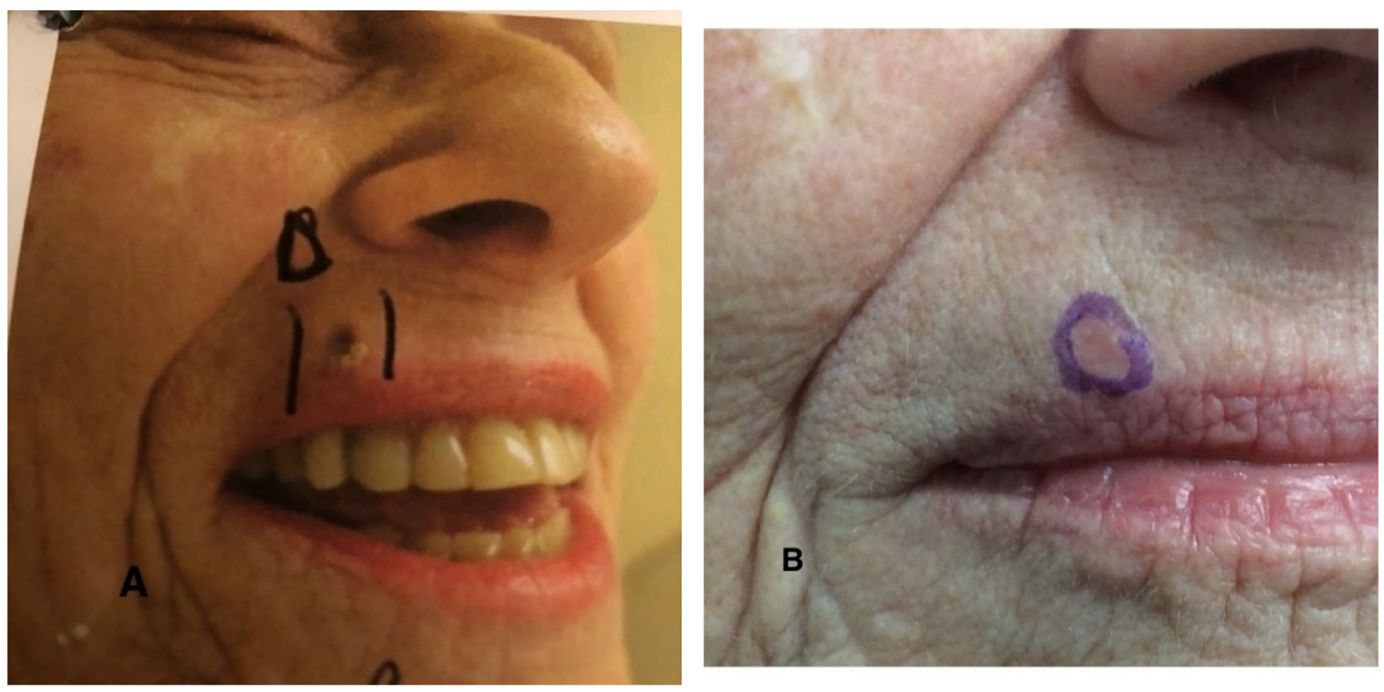

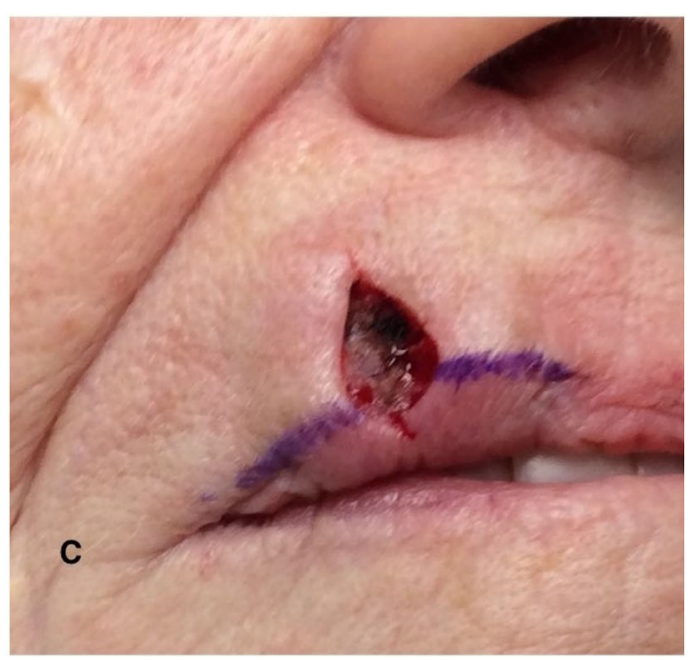

Fig. 1 a-d An 82-year-old woman developed a basal cell carcinoma on the right side of her upper lip. The upper lip, right side, was the site of the non-healing scratch. a Photograph of the site after a shave biopsy had been performed to determine the diagnosis of the persistent skin lesion (below the purple triangle and between the purple linear lines); the surface of the lesion has been cauterized. $\mathbf{b}$ The residual basal cell carcinoma, which is located at the

surgery), is a very effective management strategy for these tumors. However, the clinical presentation of basal cell carcinoma can vary, and there are several potential treatment modalities available for patients.

This article does not contain any new studies with human or animal subjects performed by any of the authors.

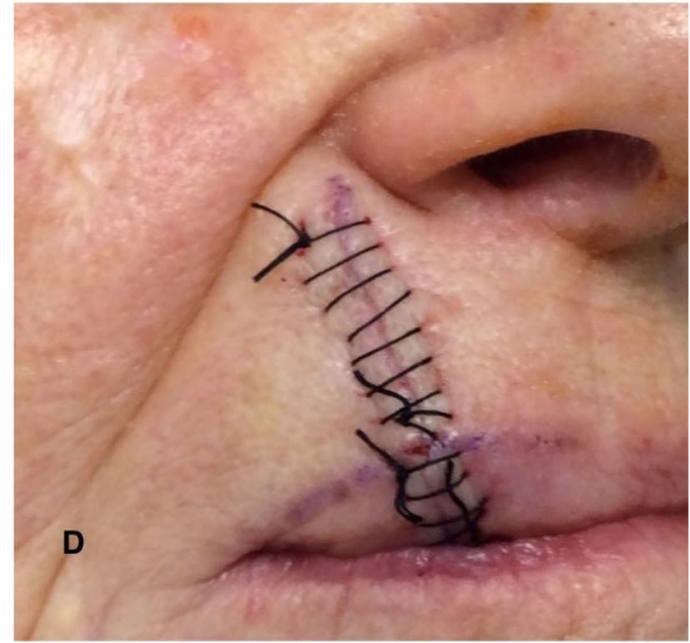

biopsy site (circled in purple ink), appears as a flesh-colored nodule. $\mathbf{c}$ Mohs surgery (with the tumor being cleared after taking one surgical stage) was performed to excise the skin cancer; purple ink (extending from the surgery-created tumor-free wound) marks the vermillion border between the cutaneous and mucosal upper lip. d The surgical wound was modified into an ellipse; the wound was subsequently sutured in a side-to-side manner

Sun exposure (ultraviolet A and ultraviolet B radiation) is the most common risk factor for developing basal cell carcinoma. Indeed, basal cell carcinoma occurs more frequently in individuals with certain physical features: blue or green eyes, freckles, blond or red hair, fair or light skin color, and always burning and never tanning after being exposed to the sun. 


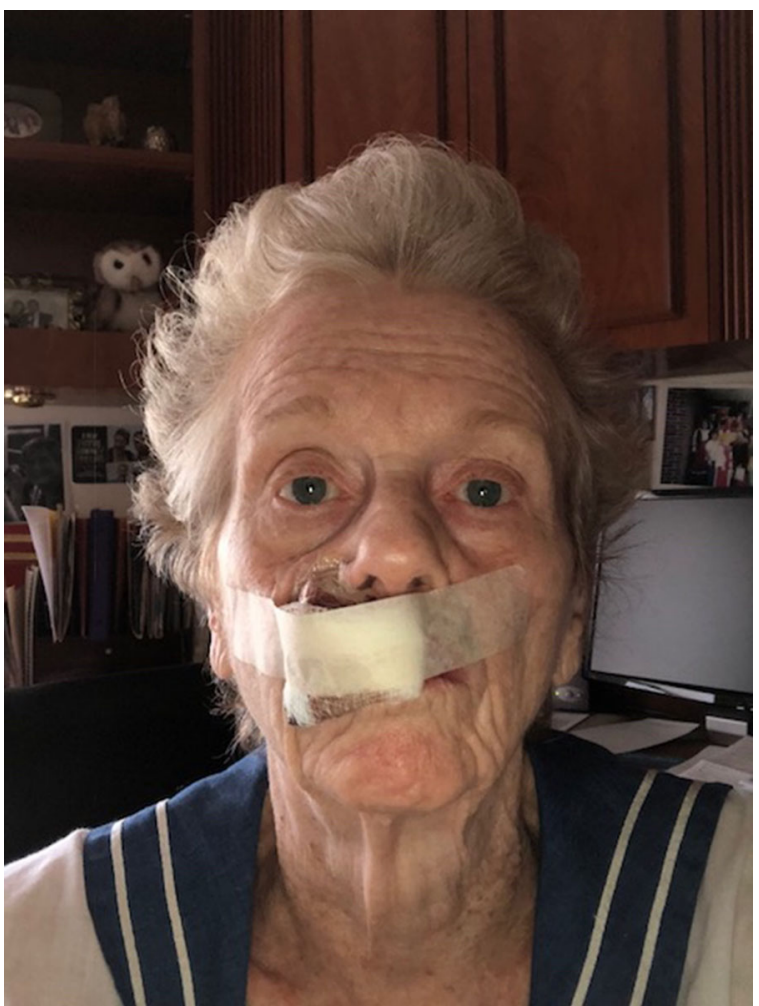

Fig. 2 Photograph of the patient taken postoperatively showing a bulky pressure dressing on her upper lip

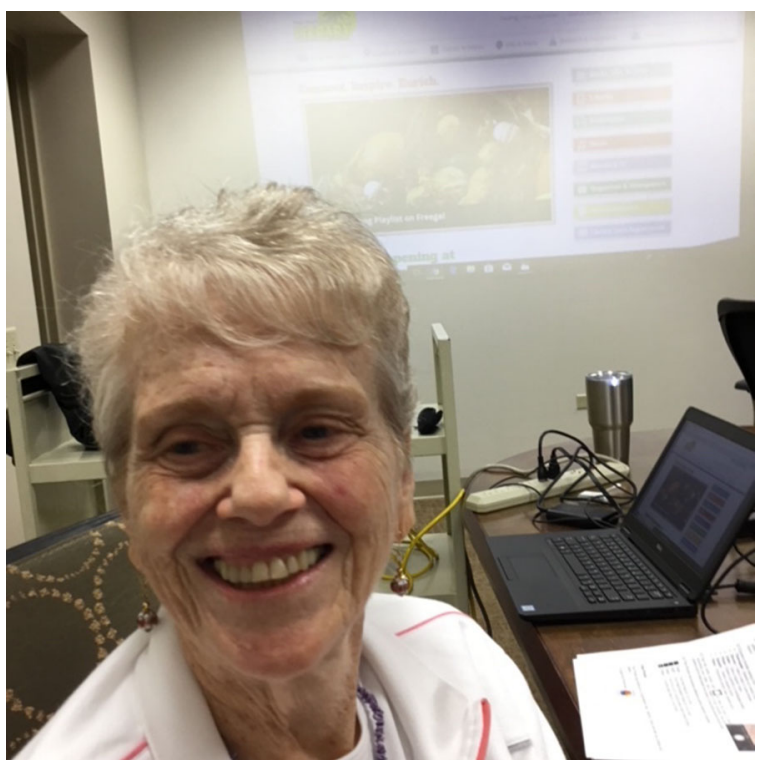

Fig. 3 Distant view of the patient's face shows the upper lip following complete healing of the surgical site

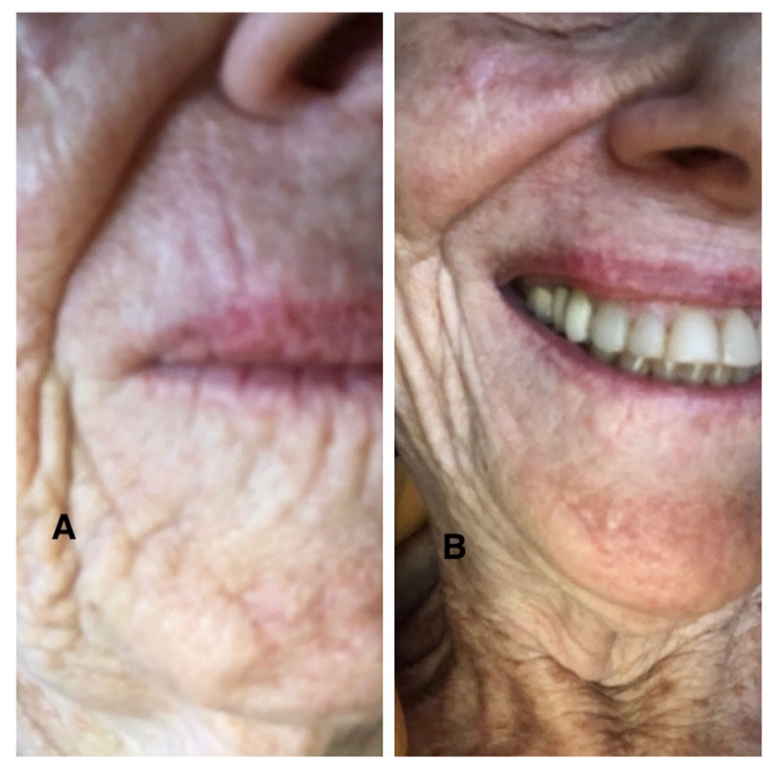

Fig. 4 Closer views of the upper lip-no smiling (a) and smiling (b) - show that the surgical site has healed nicely and that the scar is well placed among the other skin folds on the upper lip

Genomic analysis of basal cell carcinoma tumors has associated the cancer with an aberration of the Hedgehog pathway, with mutations affecting the PTCH1 (patched 1) gene [2-5].

Other risk factors also contribute to the pathogenesis of basal cell carcinoma. These include exposure to either an environmental toxin (such as arsenic, coal tar, and paraffin) and or to other sources of radiation, such as tanning beds and ionizing radiotherapy. Injuries to the skin (such as burns or chronic trauma) can also promote the development of this skin cancer. In addition, immunosuppression is a risk factor that can predispose an individual to develop basal cell carcinoma-either iatrogenic-related secondary to the medications to prevent rejection in the recipients of solid organ transplants or viral-associated in individuals with human immunodeficiency virus infection. Also, basal cell carcinoma is more prevalent in patients with certain inherited disorders; some of these genodermatoses include basal cell nevus syndrome, Bazex syndrome, epidermolysis bullosa simplex (Dowling Meara subtype), oculocutaneous albinism, Rombo syndrome, and xeroderma pigmentosa [3, 4, 6-9]. 
In addition to nodular basal cell carcinomas-similar to that of Ms. Cohen's skin cancer-that appear as telangiectatic or fleshcolored, smooth or ulcerated smaller papules of $<5 \mathrm{~mm}$ or as larger nodules of $>6 \mathrm{~mm}$, the clinical presentation of these cancers can be variable (Table 1) [5, 6, 10-19]. They also frequently appear as red plaques (superficial basal cell carcinomas) or white indurated scar-like flat lesions (infiltrated basal cell carcinomas) [3]. Less commonly, they present as pedunculated tag-like lesions often on the abdomen (fibroepithelioma of Pinkus) $[14,17]$ or red flat macules frequently on the face that mimic telangiectasias (red dot basal cell carcinomas) [11, 12, 15] or brown or black papules or patches that mimic melanocytic tumors (pigmented basal cell carcinomas) $[6,18]$. In seldom cases, basal cell carcinomas are linear in morphology [18] or advanced cancers [5] or giant-sized tumors [19]; metastatic basal cell carcinomas with tumor that has spread to other organs, such as the lung or liver, are extraordinarily rare [10, 13].

Mrs. Cohen's basal cell carcinoma occurred on her upper cutaneous lip and extended beyond the vermillion border into her mucosal lip. Indeed, similar to her tumor, most basal cell carcinomas occur on skin that has been directly exposed to the sun. However, albeit less common, basal cell carcinomas can occur at usual

Table 1 Clinical types of basal cell carcinoma

\section{Clinical types of basal cell carcinoma}

Advanced

Fibroepithelioma of Pinkus

Giant

Infiltrating (morpheaform or sclerosing)

Linear

Metastatic

Nodular

Pigmented

Red dot

Superficial
Table 2 Histologic types of basal cell carcinoma

\begin{tabular}{l} 
Histologic types of basal cell carcinoma \\
\hline Amyloid deposit-associated \\
Fibroepithelioma of Pinkus \\
Granular cell \\
Infiltrative (morpheaform or sclerosing) \\
Infundibulocystic \\
Keratotic \\
Nodular \\
Metatypical (basosquamous) \\
Mixed \\
Micronodular \\
Myoepithelial differentiation \\
Ossification-associated \\
Pigmented \\
Pleomophic \\
Superficial \\
\hline
\end{tabular}

sites, at locations that have been shielded from the sun, or both; these include the axilla $[6,16]$, breast and nipple [20], buttock and perianal area [21], foot, groin, penis and scrotum, periungual and subungual area (adjacent and beneath the nail) $[22,23]$, umbilicus [24], and vulva.

Each of the clinical variants of basal cell carcinoma has corresponding pathologic features (Table 2) [3, 6, 14, 17-19, 25-33]. Tumors with fibroepithelioma of Pinkus, keratotic, infundibulocystic, nodular, and superficial pathologic growth patterns are at lower risk for persistence following treatment as compared to those tumors with a more aggressive pathology subtype, such as basosquamous, infiltrative, micronodular, and mixed [3, 26, 27, 30]. Less common pathologic variants (such as pigmented [6, 18], granular [28] and pleomorphic $[29,31]$ subtypes) and tumors with either associated amyloid [32] or myoepithelial differentiation [25] or osteoma cutis [33] typically demonstrate less aggressive biologic behavior. 
A combination of clinical characteristics and pathologic features of the tumor are consistent with basal cell carcinomas that have a higher risk for persistence (which is manifested clinically by recurrence) following treatment (Table 3) [3, 34]. The therapeutic intervention of choice for high-risk basal cell carcinomas is Mohs micrographic surgery-the treatment that Mrs. Cohen received [34, 36]. Traditionally, the surgeon who removes the cancer also performs the microscopic evaluation of that surgical specimen. This technique allows for evaluation of the entire peripheral margin of excision during the surgical process in order to confirm that the cancer has been completely removed; if residual tumor is noted, addition layers of tissue-at the sites indicated from examination of the prior skin specimen-are taken until a tumor-free border is achieved. Then, the surgical wound is repaired.

In addition to Mohs micrographic surgery, there are other surgical, nonsurgical, and systemic treatments for basal cell carcinoma (Table 4) [5, 10, 13, 34, 35, 37-41]. Systemic

Table 3 Features of high-risk basal cell carcinomas

Features of high-risk basal cell carcinomas

Aggressive pathologic growth pattern

Borders of tumor: poorly defined

Immunosuppressed patient

Location and corresponding size of tumor

Trunk and extremities (excluding hands, feet, nail units, pretibial and ankles): $\geq 20 \mathrm{~mm}$

Cheeks, forehead, scalp, neck and pretibial $: \geq 10 \mathrm{~mm}$

Central face, eyelids, eyebrows, periorbital skin, nose, lips, chin, mandible, preauricular and postauricular skin/sulci, temple, ear, genitalia, hands and feet:

$\geq 1 \mathrm{~mm}$ (all of these locations constitute high-risk

basal cell carcinoma independent of the tumor size)

Perineural tumor involvement microscopically

Radiation therapy previously at the tumor site

Recurrent tumors
Table 4 Treatment of basal cell carcinoma

Treatment of basal cell carcinoma

Nonsurgical intervention

Cryosurgery

Photodynamic therapy

Radiation therapy

Topical therapies: 5-fluorouracil, imiquimod

Surgical intervention

Curettage and electrodessication

Excision (standard)

Mohs micrographic surgery

Systemic interventions

Immune checkpoint inhibitors: nivolumab

Smoothened inhibitors: sonidegib, vismodegib

treatments are considered for individuals with either giant, advanced, or metastatic basal cell carcinomas $[5,10,13]$. Radiation therapy may be considered for patients for whom surgery is not feasible or is contraindicated; in addition, adjuvant radiotherapy may be recommended for some individuals with high-risk basal cell carcinomas-such as patients whose tumors have perineural invasion or have not been able to achieve a tumor-free margins of excision, or both $[34,35,41]$. Nonsurgical topical interventions may be considered in patients with superficial basal cell carcinomas $[34,35,37,38,40]$. However, the cure rates of other treatment modalities are lower than those observed in patients whose tumors have been excised using Mohs micrographic surgery.

\section{OUR PATIENT}

Mrs. Cohen presented to me with a persistent lesion on her upper lip. She has the phenotypic features that have been associated with an increased risk for the development of skin cancer, two prior basal cell carcinomas on her face, and a history of actinic keratoses that have 
regularly been treated with liquid nitrogen cryotherapy. Mrs. Cohen was convinced this was only a scratch that was slow to heal; indeed, non-neoplastic conditions can mimic a basal cell carcinoma [42]. Also, bacterial or mycobacterial infection and basal cell carcinoma can be present in the same lesion [43]. However, I suspected that Mrs. Cohen had a new basal cell carcinoma and performed a biopsy to establish the diagnosis.

The report from the dermatopathologist confirmed the diagnosis of a nodular basal cell carcinoma. I referred Ms. Cohen to a Mohs surgeon to have the cancer removed. Her tumor was cleared after one stage of excision, and the Mohs surgeon was able to repair the surgical wound with a side-to-side closure.

Mrs. Cohen has achieved an excellent functional and cosmetic result following the treatment of her upper lip basal cell carcinoma. She and I have discussed that after a patient develops a basal cell carcinoma, there is between a $30-70 \%$ cumulative risk of developing another basal cell carcinoma within the next 3 years [44-47]. Therefore, I will continue to regularly see Mrs. Cohen for total body skin checks.

\section{ACKNOWLEDGEMENTS}

Funding. The authors are fully responsible for all content and editorial decisions and received no financial support or other form of compensation related to the development of this manuscript. No funding was received for publication of this article.

Authorship. All named authors meet the International Committee of Medical Journal Editors (ICMJE) criteria for authorship of this manuscript, take responsibility for the integrity of the work as a whole, and have given final approval for the version to be published. The opinions expressed in the manuscript are those of the authors.

Disclosures. Barbara J. Cohen, Eliahou S. Cohen, and Philip R. Cohen have nothing to disclose with regards to the publication of this article.

Compliance with Ethics Guidelines. This article does not contain any new studies with human or animal subjects performed by any of the authors.

Peer Review. Please note, contrary to the journal's standard double-blind peer review process, as a commentary this article underwent review by a member of the journal's Editorial Board.

Open Access. This article is distributed under the terms of the Creative Commons Attribution-NonCommercial 4.0 International License (http://creativecommons.org/licenses/ by-nc/4.0/), which permits any noncommercial use, distribution, and reproduction in any medium, provided you give appropriate credit to the original author(s) and the source, provide a link to the Creative Commons license, and indicate if changes were made.

\section{REFERENCES}

1. Cohen PR. Basal cell carcinoma. J Gt Houst Dent Soc. $1995 ; 67(1): 20-1$.

2. Bakshi A, Chaudhary SC, Rana M, Elmets CA, Athar M. Basal cell carcinoma pathogenesis and therapy involving hedgehog signaling and beyond. Mol Carcinog. 2017;56(12):2543-57.

3. Prieto-Granada C, Rodriguez-Waitkus P. Basal cell carcinoma: epidemiology, clinical and histologic features, and basic science review. Curr Probl Cancer. 2015;39:198-205.

4. Verkouteren JAC, Ramdas KHR, Wakke M, Nijsten T. Epidemiology of basal cell carcinoma: scholarly review. Br J Dermatol. 2017;177(2):359-72.

5. Goodman AM, Kato S, Cohen PR et al. Genomic landscape of advanced basal cell carcinoma: implications for precision treatment with targeted and immune therapies. Oncoimmunology. 2017;7(3):e1404217.

6. Cohen PR. Axillary basal cell carcinoma in patients with Goltz-Gorlin syndrome: report of basal cell carcinoma in both axilla of a woman with basal cell 
nevus syndrome and literature review. Dermatol Online J 2014;20(8). pii: 13030/qt7pg665b9.

7. Griffin JR, Cohen PR, Tschen JA et al. Basal cell carcinoma in childhood: case report and literature review. J Am Acad Dermatol. 2007;57[5 Suppl]:S97-102.

8. Cohen PR. Genodermatoses with malignant potential. Am Fam Physician. 1992;45(5):1479-86.

9. Witmanowski H, Szychta P, Blochowiak K, Jundzill A, Czajkowski R. Basal cell nevus syndrome (GorlinGoltz syndrome): genetic predisposition, clinical picture and treatment. Postepy Dermatol Alergol. 2017;34(4):381-7.

10. Cohen PR, Kato S, Goodman AM, Ikeda S, Kurzrock R. Appearance of new cutaneous superficial basal cell carcinomas during successful nivolumab treatment of refractory metastatic disease: implications for immunotherapy in early versus late disease. Int J Mol Sci 2017;18(8). https://doi.org/10.3390/ ijms18081663

11. Cohen PR. Red dot basal cell carcinoma. J Clin Aesthet Dermatol. 2017;10(5):56-8.

12. Cohen PR. Red dot basal cell carcinoma: report of cases and review of this unique presentation of basal cell carcinoma. Cureus. 2017;9(3):e1110.

13. Ikeda S, Goodman AM, Cohen PR, et al. Metastatic basal cell carcinoma with amplification of PD-L1: exceptional response to anti-PD1 therapy. NPJ Genom Med 2016;1. https://doi.org/10.1038/ npjgenmed.2016.37.

14. Haddock ES, Cohen PR. Fibroepithelioma of Pinkus revisited. Dermatol Ther (Heidelb). 2016;6(3):347-62.

15. Loh TY, Cohen PR. Red dot basal cell carcinoma: an unusual variant of a common malignancy. J Drugs Dermatol. 2016;15(5):645-7.

16. Cohen PR. Basal cell carcinoma of the axilla: review of the world literature. Am J Clin Dermatol. 2014;15(2):95-100.

17. Cohen PR, Tschen JA. Fibroepithelioma of Pinkus presenting as a sessile thigh nodule. Skinmed. 2003;2(6):385-7.

18. Chopra KF, Cohen PR. Linear basal cell carcinoma: report of multiple sequential tumors localized to a radiotherapy port and review of the literature. Tex Med. 1997;93(7):57-9.

19. Purnell JC, Gardner JM, Brown JA, Shalin SC. Conventional versus giant basal cell carcinoma, a review of 57 cases: histologic differences contributing to excessive growth. Indian J Dermatol. 2018;63(2):147-54.

20. Chun KA, Cohen PR. Basal cell carcinoma of the nipple-areola complex: a comprehensive review of the world literature. Dermatol Ther (Heidelb). 2016;6(3):379.

21. Cohen PR. Basal cell carcinoma of the buttock. Skinmed. 2018;16(2):114-9.

22. Shimizu I, Cohen PR, Macfarlane DF. Surgical treatment of basal cell carcinoma of the nail unit. Int J Dermatol. 2013;52(8):996-8.

23. Martinelli PT, Cohen PR, Schulze KE, Dorsey KE, Nelson BR. Periungual basal cell carcinoma: case report and literature review. Dermatol Surg. 2006;32(2):320-3.

24. Narala S, Cohen PR. Basal cell carcinoma of the umbilicus: a comprehensive literature review. Cureus. 2016;8(9):e770.

25. Cohen PR. Basal cell carcinoma with myoepithelial differentiation: case report and literature review. Cureus. 2018;10(1):e2081.

26. Cohen PR. Cancer-associated perineural invasion versus reexcision-associated perineural invasion. J Cutan Pathol. 2011;38(1):78-9.

27. Cohen PR, Schulze KE, Nelson BR. Basal cell carcinoma with mixed histology: a possible pathogenesis for recurrent skin cancer. Dermatol Surg. 2006;32(4):542-51.

28. Ma X, Wang G, Kuwadekar A et al. Granular cell basal cell carcinoma: a case report. J Cutan Pathol. 2018;45(3):223-5.

29. Tschen JP, Cohen PR, Schulze KE, Tschen JA, Nelson BR. Pleomorphic basal cell carcinoma: case reports and review. South Med J. 2006;99(3):296-302.

30. Cohen PR, Schulze KE, Nelson BR. Cutaneous carcinoma with mixed histology: a potential etiology for skin cancer recurrence and an indication for Mohs microscopically controlled surgical excision. South Med J. 2005;98(7):740-7.

31. Garcia JA, Cohen PR, Herzberg AJ, Wallis ME, Rapini RP. Pleomorphic basal cell carcinoma. J Am Acad Dermatol. 1995;32(5 Pt 1):740-6.

32. Satti MB, Azzopardi JG. Amyloid deposits in basal cell carcinoma of the skin: a pathologic study of 199 cases. J Am Acad Dermatol. 1990;22:1082-7.

33. Boyd AS, King LE. Basal cell carcinoma with ossification. J Am Acad Dermatol. 1998;38:906-10. 
34. Work Group; Invited Reviewers, Kim JYS et al. Guidelines of care for the management of basal cell carcinoma. J Am Acad Dermatol 2018; 78(3):540-559.

35. Telfer NR, Colver GB, Morton CA. Guidelines for the management of basal cell carcinoma. Br J Dermatol. 2008;159:35-48.

36. Eliezri Y, Cohen PR. Cancer recurrence following Mohs micrographic surgery: a mechanism of tumor persistence. Plast Reconstr Surg. 1992;90(1):121-5.

37. Maytin EV, Kaw U, Ilyas M, Mack JA, Hu B. Blue light versus red light for photodynamic therapy of basal cell carcinoma in patients with Gorlin syndrome: a bilaterally controlled comparison study. Photodiagn Photodyn Ther. 2018. https://doi.org/ 10.1016/j.pdpdt.2018.02.009.

38. Ariza S, Espinosa S, Naranjo M. Nonsurgical therapies for basal cell carcinoma: a review. Actas Dermosifiliogr. 2017;108(9):809-17.

39. Lanoue J, Goldenberg G. Basal cell carcinoma: a comprehensive review of existing and emerging nonsurgical therapies. J Clin Aesthet Dermatol. 2016;9(5):26-36.

40. Hanna E, Abadi R, Abbas O. Imiquimod in dermatology: an overview. Int $\mathrm{J}$ Dermatol. 2016;55(8):831-44.

41. Alter M, Hillen U, Leiter U, Sachse M, Gutzmer R. Current diagnosis and treatment of basal cell carcinoma. J Dtsch Dermatol Ges. 2015;13(9):863-74.
42. Cohen PR, Eliezri YD. Cutaneous odontogenic sinus simulating a basal cell carcinoma: case report and literature review. Plast Reconstr Surg. 1990;86(1):123-7.

43. Ratoosh SL, Cohen PR, Troncoso P. Cutaneous malignancy and leprosy. Report of a patient with Mycobacterium leprae and basal cell carcinoma concurrently present in the same lesion. J Dermatol Surg Oncol. 1994;20(9):613-8.

44. Karagas MR, Stukel TA, Greenberg ER, Baron JA, Mott LA, Stern RS. Risk of subsequent basal cell carcinoma and squamous cell carcinoma of the skin among patients with prior skin cancer. Skin Cancer Prevention Study Group. JAMA. 1992;267(24):3305-10.

45. Marcil I, Stern RS. Risk of developing a subsequent nonmelanoma skin cancer in patients with a history of nonmelanoma skin cancer: a critical review of the literature and meta-analysis. Arch Dermatol. 2000;136(12):1524-30.

46. Ramachandran S, Rajaratnam R, Smith AG, Lear JT, Strange RC. Patients with both basal and squamous cell carcinomas are at a lower risk of further basal cell carcinomas than patients with only a basal cell carcinoma. J Am Acad Dermatol. 2009;61(2):247-51.

47. Flohil SC, van der Leest RJ, Arends LR, de Vries E, Nijsten T. Risk of subsequent cutaneous malignancy in patients with prior keratinocyte carcinoma: a systematic review and meta-analysis. Eur J Cancer. 2013;49(10):2365-75. 